\title{
Comparison of Leifsonia xyli subsp. xyli molecular detection in heat-treated sugarcane setts ${ }^{1}$
}

\author{
Vanessa Duarte Dias ${ }^{2}$, Renato Carrer Filho ${ }^{2}$, Marcos Gomes da Cunha ${ }^{2}$
}

\section{ABSTRACT}

The thermotherapy of sugarcane setts is currently the primary management method for Leifsonia xyli subsp. xyli $(L x x)$, in Brazil. When they are immersed, the enzymes and proteins of the bacterial cell are denatured without harming the setts buds. Due to possible escapes from detection and consequent bacterium survival to thermotherapy, what may result in asymptomatic seedlings, this study aimed to detect the Leifsonia xyli subsp. $x y l i$ bacterium in sugarcane setts using molecular techniques and different time and temperature combinations, with or without the addition of antibiotics. The conventional PCR method detected the Lxx bacterial DNA only in the positive control, consisting of a highly susceptible plant with a high bacterial concentration. Using the nested-PCR, the Lxx DNA was detected in all the treatments used. Thus, none of the treatments adopted in the thermotherapy was able to eliminate the $L x x$ from the setts, and the use of kasugamicin also did not eliminate the bacterium, but reduced the bacterial population in the tested treatments. These results confirm that the nested-PCR is a useful tool to detect the presence of this phytobacterium in setts that will be used as seedlings.

KEYWORDS: Heat treatment, ratoon stunting disease, polimerase chain reaction.

\section{INTRODUCTION}

The ratoon stunting disease (RSD), caused by the fastidious gram-positive bacteria Leifsonia $x y l i$ subsp. $x y l i(L x x)$, is the most important sugarcane disease. Production losses may exceed $50 \%$, depending on the susceptibility of the genotype (Davis \& Bailey 2000, Young \& Brumbley 2004, Grisham et al. 2009) and environmental conditions (Ngaruiya et al. 2005), primarily under prolonged drought (Brumbley et al. 2006, Ramos 2012). Losses are also directly related to the bacterial titer.

\section{RESUMO}

Comparação de detecção molecular de Leifsonia xyli subsp. xyli em toletes de cana-de-açúcar tratados termicamente

O tratamento térmico de toletes para a formação de mudas de cana-de-açúcar é a principal forma de manejo de Leifsonia xyli subsp. xyli ( $L x x)$, atualmente, no Brasil. Quando imersos, as enzimas e proteínas da célula bacteriana são desnaturadas, sem causar prejuízos às gemas dos toletes. Devido a possíveis escapes à detecção e consequente sobrevivência da bactéria à termoterapia, $\mathrm{o}$ que pode dar origem a mudas assintomáticas, objetivou-se realizar a deteç̧ão da bactéria Leifsonia xyli subsp. xyli em toletes de cana-de-açúcar, utilizando-se técnicas moleculares e combinações de tempo e temperatura, com ou sem a adição de antibióticos. A técnica PCR convencional detectou o DNA bacteriano de $L x x$ somente no controle positivo, constituído de planta altamente suscetível, com alta concentração bacteriana. Já pela nested-PCR, o DNA de Lxx foi detectado em todos os tratamentos utilizados. Assim, nenhum dos tratamentos adotados na termoterapia foi capaz de eliminar a $L x x$ dos toletes, bem como o uso de kasugamicina também não propiciou a eliminação da bactéria, mas reduziu sua população nos tratamentos testados. Estes resultados atestam a nested-PCR como ferramenta útil para a comprovação da presença da fitobactéria em toletes que serão utilizados como mudas.

PALAVRAS-CHAVE: Termoterapia, raquitismo-das-soqueiras, reação em cadeia da polimerase.

Harrison \& Davis (1998) correlated the resistance of sugarcane cultivars to ratoon stunting disease with low $L x x$ density in the xylem sap, and greater production losses were found in crops with high concentrations of the pathogen (Davis et al. 1998, Zekarias et al. 2012).

Bacterial survival is closely linked to the presence of sugarcane in the field, and its transmission occurs mainly during the crop cycles that include plantation renewal. As such, this disease has been controlled based on exclusion methods, primarily the use of healthy material in crops resulting from 
the heat treatment of setts (Damann \& Benda 1983) or in vitro growing of meristems (Hoy et al. 2003, Sandhu et al. 2009).

The absence of resistant varieties and asymptomatic conditions in infected plants hinder the management, diagnosis and, consequently, correct identification of phytobacteria. As such, management practices become inadequate, and selecting resistant varieties in breeding programs is difficult (Gagliardi \& Camargo 2009).

Laboratory diagnoses have improved due to the importance of ensuring the detection and correct identification of the phytopathogenic agent. Among the most widely used detection methods are light microscopy, the Enzyme-linked Immunosorbent Assay (ELISA) test, Evaporative-binding Enzymelinked Immonoassay (EB-EIA), Tissue Blot Enzyme Immunoassay (TB-EIA) and Dot Blot Enzyme Immunoassay (Iglesias 2003, Carneiro et al. 2004, Urashima \& Grachet 2012). However, these techniques are time-consuming, not sensitive when compared to molecular techniques, and do not detect low bacterial concentrations in host tissue cells.

Methods based on the Polimerase Chain Reaction (PCR) technique are more sensitive and specific for diagnosis than immunoassays (Iglesias 2003). Recent studies have used the Taqman ${ }^{\circledR}$ qPCR system to identify Lxx (Pelosi et al. 2013). However, the technique is difficult to apply in large-scale routine analysis, because it is quite laborious and requires specific sophisticated equipment (Dias et al. 2018).

As such, this study aimed to evaluate PCR and nested-PCR as tools to detect Leifsonia xyli subsp. $x y l i$ in sugarcane stalks, heat-treated, combining times and temperatures, with or without the addition of antibiotics.

\section{MATERIAL AND METHODS}

Two independent experiments were carried out. The first was conducted at the Universidade Federal de Goiás, in Goiânia, and the second at the Jalles Machado power plant, in Goianésia, both in the Goiás state, Brazil, in 2014.

In the first test, one-bud setts were used for heat treatment. These were sampled in 9-monthold CB 460 stalks, which are susceptible to ratoon stunting disease. In the second test, 3-bud setts of the most widely grown commercial variety around
Goianésia (RB92579) were tested at 9 months of age. In both samples, analyses confirmed the presence of ratoon stunting disease by detecting the bacterial pathogen using the conventional PCR method and species-specific primers (Taylor et al. 2003).

For the first test (heat treatment of onebud setts), the stalks were collected and cut to an average length of $8 \mathrm{~cm}$. For each treatment, 30 setts were packed in burlap bags to facilitate handling and submitted to heat treatment in a water bath (Thermo Scientific, Model 260) containing distilled water, with or without the addition of the antibiotic kasugamycin, at a dose of $300{\mathrm{~mL} 100 \mathrm{~L}^{-1}}^{-}$ of $\mathrm{H}_{2} \mathrm{O}$. The experiment consisted of 10 treatments: $\mathrm{T} 1=52{ }^{\circ} \mathrm{C} / 30 \mathrm{~min} ; \mathrm{T} 2=52{ }^{\circ} \mathrm{C} / 1 \mathrm{~h} ; \mathrm{T} 3=50{ }^{\circ} \mathrm{C} / 1 \mathrm{~h}$; $\mathrm{T} 4=50^{\circ} \mathrm{C} / 2 \mathrm{~h} ; \mathrm{T} 5=52{ }^{\circ} \mathrm{C} / 30 \mathrm{~min}+$ kasugamycin; $\mathrm{T} 6=52^{\circ} \mathrm{C} / 1 \mathrm{~h}+$ kasugamycin; $\mathrm{T} 7=50^{\circ} \mathrm{C} / 30 \mathrm{~min}+$ kasugamicina; $\mathrm{T} 8=50^{\circ} \mathrm{C} / 1 \mathrm{~h}+$ kasugamycin; $\mathrm{T} 9=$ kasugamycin (immersed in kasugamycin at a dose

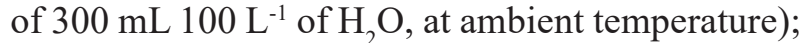
$\mathrm{T} 10=$ control (immersed in water at ambient temperature).

After the treatment, the setts were distributed into plastic trays $(39 \mathrm{~cm} \times 28 \mathrm{~cm} \times 10 \mathrm{~cm})$ containing Biofértil ${ }^{\circledR}$ substrate. The trays were placed in a greenhouse, with an average temperature of $30{ }^{\circ} \mathrm{C}+/-3^{\circ} \mathrm{C}$ and relative humidity varying between $50 \%$ and $70 \%$. At 30 days after planting, ten setts from each treatment measuring about $30 \mathrm{~cm}$ in height were transplanted to the field and arranged in completely randomized plots. At 9 months after the transplantation, three samples per treatment were collected for molecular diagnosis. Setts were cut from the base of each stalk, washed, peeled and the cross-section removed. These sections were subjected to pressure in a press and the fibrovascular fluid was collected in $2 \mathrm{~mL}$ microtubes, which were stored at $20{ }^{\circ} \mathrm{C}$ until processing.

For the second test (heat treatment of threebud setts), the stalks were collected in raffia bags and immersed in water with or without adding kasugamycin, at different time-temperature combinations. The experiment consisted of the same 10 treatments described in the first test.

Immediately after the treatments, the setts were distributed in the field and arranged in completely randomized plots. Each plot contained four 5-m-long rows. Samples were randomly collected from 10 stalks per treatment, at 9 months after planting. The fibrovascular fluid was extracted from the basal part 
of each stalk using positive pressure, with the help of a compressor, and collected in $2 \mathrm{~mL}$ microtubes, which were stored at $20^{\circ} \mathrm{C}$ until processing.

For the genomic DNA extractions in the first test, $2 \mathrm{~mL}$ samples of fibrovascular fluid from each treatment were used to extract the total DNA via the CTAB 2X method (Boiteux et al. 1999). For the second test, the PureLink ${ }^{\circledR}$ Plant total DNA Purification Kit was used, according to the manufacturer's instructions. All the samples were quantified in a spectrophotometer, adjusted to $20 \mathrm{ng} \mathrm{mL}^{-1}$ and stored at $-20{ }^{\circ} \mathrm{C}$ until the PCR analysis.

Two protocols of different primers for amplifying specific genomic regions were used in tests with varying PCR primer pairs. The conventional PCR, with $L x x$-C2F/R (5'-CGA-GTTTGG-GTT-TCT-GCC-TGC-3') and (5'-AGG-TGGCAG-CGA-CAA-CGG-TGC-3') primers, was used to amplify a specific bacterial genomic region (Taylor et al. 2003). The nested-PCR protocol with RSD33 (5'-CTG-GCA-CCC-TGT-GTT-GTT-TTC-3') and RSD297 (5' -TTC-GGT-TCT-CAT-CrCA-GCGTC-3') primers was used for the first PCR, and RST60 (5'-TCA-ACG-CAG-AGA-TTG-TCC-AG-3') and RST59 (5'-CGT-CTT-GAA-GAC-ACA-GCG-ATGAG-3') for the nested-PCR (Davis et al. 1998).

For each PCR region, 5.0 $\mu \mathrm{L}$ of Premix $2 \mathrm{X}$ (EmeraldAmp ${ }^{\circledR}$ GT PCR Master Mix), a $2 \mu$ L aliquot of DNA extracted from stalk samples or pure $L x x$ culture, at $20 \eta \mathrm{g} \mu \mathrm{L}^{-1}, 0.2 \mu \mathrm{L}$ of each primer at $2.5 \mu \mathrm{M}$ and $3.6 \mu \mathrm{L}$ of ultrapure water to top up to a final volume of $10 \mu \mathrm{L}$ were used. A single PCR protocol was used for all the markers, consisting of denaturation at $94{ }^{\circ} \mathrm{C}$ for $2 \mathrm{~min}$, followed by 35 cycles of initial denaturation at $94^{\circ} \mathrm{C}$ for $40 \mathrm{~s}$, primer annealing at $54{ }^{\circ} \mathrm{C}$ for $40 \mathrm{~s}$, extension at $72{ }^{\circ} \mathrm{C}$ for $45 \mathrm{~s}$ and final extension at $72^{\circ} \mathrm{C}$ for $10 \mathrm{~min}$. The PCR tests were conducted in a Biocycler thermocycler $\left(\right.$ Biosystem $\left.^{\circledR}\right)$. All the PCR products were separated in $1.5 \%$ agarose gel, precast with GelRed in TBE buffer and submitted to electrophoresis at $80 \mathrm{~V}$, and visualized in a UV transilluminator.

To simulate the bacteria detection in the host, PCR and nested-PCR sensitivity tests were conducted using total DNA extracted from healthy sugarcane mixed with genomic DNA extracted from $L x x$ bacteria, obtained after 14 days of growth in MSC culture medium modified by MonteiroVitorello et al. (2004). The total DNA concentration in the fibrovascular fluid of sugarcane was fixed at
$20 \eta \mathrm{g} \mu \mathrm{L}^{-1}$ and the DNA of $L x x$ was quantified at an initial concentration of $25 \eta \mathrm{g} \mu \mathrm{L}^{-1}$ and serially diluted down to a concentration of $2.5 \times 10^{-6} \eta \mathrm{g} \mu \mathrm{L}^{-1}$. Next, $1 \mu \mathrm{L}$ of the initial solution of $L x x$ DNA was transferred to a tube containing $9 \mu \mathrm{L}$ of total DNA suspension of healthy sugarcane at $20 \eta g \mu \mathrm{L}^{-1}$, and then successively for each dilution of Lxx DNA $\left(10^{-7}=2.5 \times 10^{-6} \eta \mathrm{g} \mu \mathrm{L}^{-1}\right)$. Thus, instead of using water for the serial dilution, DNA extracted from the fibrovascular fluid of healthy sugarcane was used to have a sensitive parameter to detect bacterial DNA when mixed with total DNA from sugarcane. Conventional PCR amplifications were performed with the different dilutions and then using nestedPCR with primers designed by Davis et al. (1998), as previously described.

The Sanger method was applied to verify the DNA sequences of products amplified by nested-PCR. Ten samples of nested-PCR amplification products were randomly selected to confirm the identity of the pathogen. The purification of previously amplified products followed the SEPHADEX G50 protocol. Sequences of ten nested-PCR amplified products were aligned using the BLAST program and compared with the isolated CTCB07 Lxx sequence, whose complete genome is deposited in the GenBank.

\section{RESULTS AND DISCUSSION}

For the first test, in the treatments conducted with one-bud setts, the analyses obtained by PCR using the primers designed by Taylor et al. (2003) showed an amplification of the expected $520 \mathrm{bp}$ band only in the positive control, i.e., in samples of susceptible field-infected plant material, where the presence of high bacterial titers of Leifsonia xyli subsp. xyli was previously confirmed in the stalk. For the remaining treatments, there were no visible amplifications for any of the heat treatments associated or not with antibiotics (Figure 1). However, amplifications were detected in at least one of the repetitions of each treatment using nested-PCR (Figure 2).

For the second test, in treatments conducted in three-bud setts, bacterial DNA amplifications were also not detected in any of the heat treatments associated or not with antibiotics, in conventional PCR reactions using the primers designed by Taylor et al. (2003). However, for nested-PCR, amplifications were visible in one or more repetitions 
of all the treatments, similarly to the results of the previous test.

Given the differences in sensitivity between conventional and nested-PCR, the performance of these two techniques in the amplifications of a serial dilution of $L x x$ DNA diluted in total DNA from healthy sugarcane, at $20 \eta \mathrm{g} \mu \mathrm{L}^{-1}$, were analyzed. Conventional PCR efficiently amplified the DNA of $L x x$ at a concentration greater than or equal to $2.5 \mathrm{x}$
$10^{-2} \eta \mathrm{g} \mu \mathrm{L}^{-1}$, whereas nested-PCR was efficient up to $2.5 \times 10^{-5} \eta g \mu L^{-1}$ (Figure 3 ). The degree of sensitivity of nested-PCR was one thousand times higher than that of conventional PCR.

Analyses of nested-PCR amplified sequences randomly selected to prove the identity of the pathogen, using the BLAST software, exhibited $100 \%$ of identity to Leifsonia xyli subsp. xyli, Culture CTCB07, whose complete genome is deposited in the GenBank.

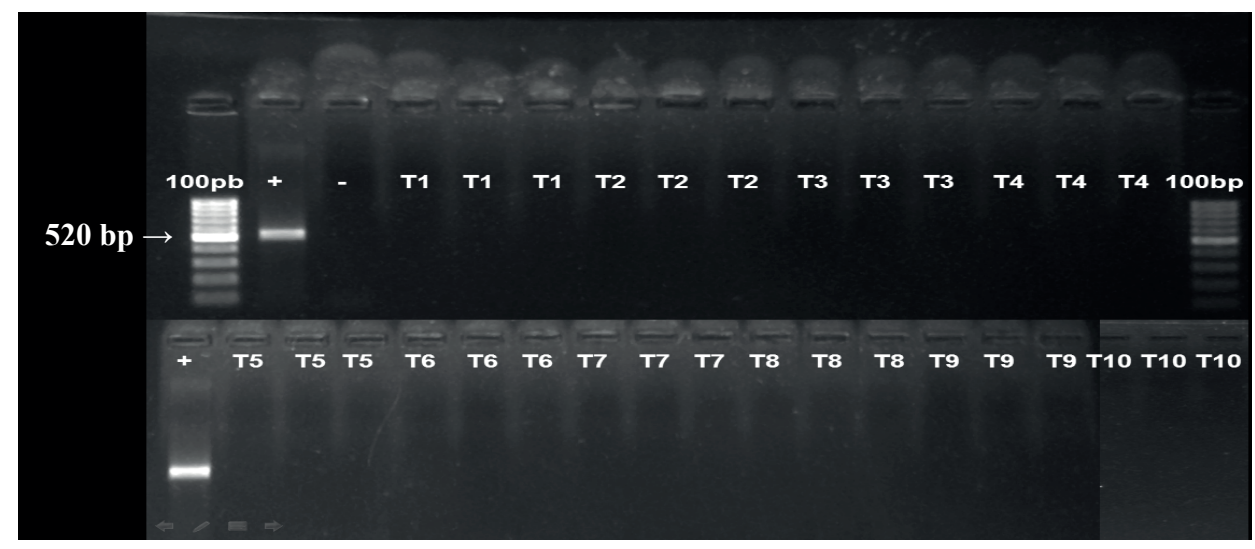

Figure 1. Conventional PCR amplifications with primers designed by Taylor et al. (2003) separated in $1.5 \%$ agarose gel, 100 base pair ladder in the first column from left to right of the gel, followed by a positive and negative control of DNA extraction and three repetitions of each treatment. $\mathrm{T} 1=52{ }^{\circ} \mathrm{C} / 30 \mathrm{~min} ; \mathrm{T} 2=52{ }^{\circ} \mathrm{C} / 1 \mathrm{~h} ; \mathrm{T} 3=50{ }^{\circ} \mathrm{C} / 1 \mathrm{~h} ; \mathrm{T} 4=50{ }^{\circ} \mathrm{C} / 2 \mathrm{~h}$; $\mathrm{T} 5=52{ }^{\circ} \mathrm{C} / 30 \mathrm{~min}+$ kasugamycin; $\mathrm{T} 6=52{ }^{\circ} \mathrm{C} / 1 \mathrm{~h}+$ kasugamycin; $\mathrm{T} 7=50^{\circ} \mathrm{C} / 30 \mathrm{~min}+$ kasugamycin; $\mathrm{T} 8=50^{\circ} \mathrm{C} / 1 \mathrm{~h}+$ kasugamycin; $\mathrm{T} 9=$ kasugamycin (immersion in $3 \mathrm{~mL} \mathrm{~L}^{-1}$ of antibiotic); $\mathrm{T} 10=$ control (immersion in water at ambient temperature).

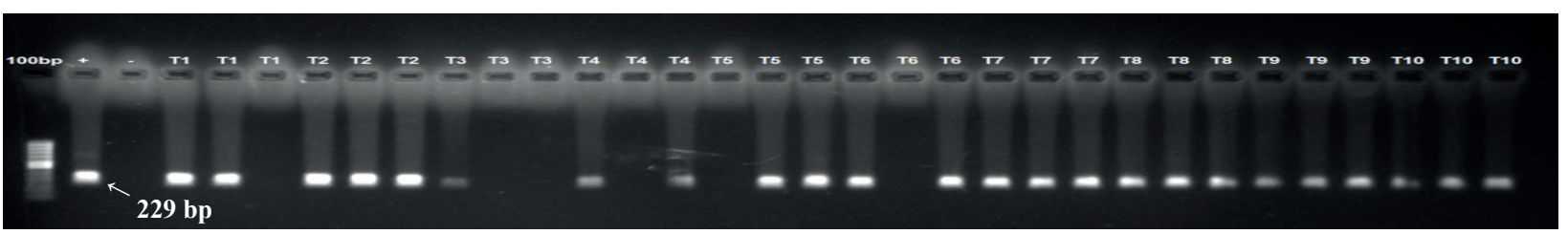

Figure 2. Nested-PCR amplifications with primers designed by Davis et al. (1998) from DNA extracted using the modified CTAB $2 \mathrm{x}$ protocol. The fragments were separated in $1.5 \%$ agarose gel, 100 base pair ladder in the first column from left to right of the gel, followed by a positive and negative control of DNA extraction and three repetitions of each treatment. $\mathrm{T} 1=52{ }^{\circ} \mathrm{C} / 30 \mathrm{~min} ; \mathrm{T} 2=52{ }^{\circ} \mathrm{C} / 1 \mathrm{~h} ; \mathrm{T} 3=50{ }^{\circ} \mathrm{C} / 1 \mathrm{~h} ; \mathrm{T} 4=50{ }^{\circ} \mathrm{C} / 2 \mathrm{~h} ; \mathrm{T} 5=52{ }^{\circ} \mathrm{C} / 30 \mathrm{~min}+$ kasugamycin; $\mathrm{T} 6=52{ }^{\circ} \mathrm{C} / 1 \mathrm{~h}+$ kasugamycin; $\mathrm{T} 7=50^{\circ} \mathrm{C} / 30 \mathrm{~min}+$ kasugamycin; $\mathrm{T} 8=50^{\circ} \mathrm{C} / 1 \mathrm{~h}+$ kasugamycin; $\mathrm{T} 9=$ kasugamycin (immersion in $3 \mathrm{~mL} \mathrm{~L}^{-1}$ of antibiotic); $\mathrm{T} 10=$ control (immersion in water at ambient temperature).

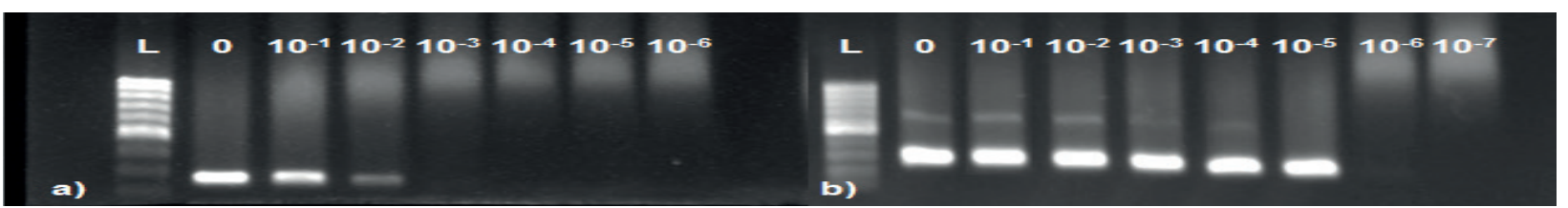

Figure 3. Comparison of sensitivity of conventional and nested-PCR for detection of $L x x$. a) Conventional amplifications up to a DNA dilution of $2.5 \times 10^{-2} \eta g \mu \mathrm{L}^{-1}$; b) nested-PCR amplification up to a DNA dilution of $2.5 \times 10^{-5} \eta \mathrm{g} \mu \mathrm{L}^{-1}$. 
The results of conventional and nestedPCR demonstrate that assessing the heat treatment efficiency is essential to avoid false negative results. When assessing using only the conventional PCR detection method, all the treatments were considered efficient in controlling Lxx, even T10 (control stalks immersed in water at ambient temperature), what contradicts this conclusion, since, under these conditions, the $L x x$ viability would not be compromised.

In contrast to conventional PCR, which showed a low $L x x$ detection sensitivity, nested-PCR clearly demonstrated that none of the heat treatments can eliminate $L x x$ populations from sugarcane stalks, using the test with both one-bud and three-bud setts.

These results show that a decline in bacterial levels in sugarcane stalks over time does not affect the sensitivity of conventional PCR detection, which remains unchanged; however, conventional PCR cannot detect very low concentrations of the bacteria, compromising the health of future field crops. Furthermore, $L x x$ was detected by nested-PCR in at least one of the samples in all the treatments proposed here, indicating bacterial survival despite the heat treatment, i.e., $L x x$ was not completely controlled after the adopted procedures. The fast and efficient detection of bacteria is one of the requirements for the successful management of the ratoon stunting disease, since, in addition to the disease being difficult to diagnose in the field due to the lack of characteristic external signs (Rao et al. 2004, Urashima \& Grachet 2012), it prevents false negatives from occurring in plant material treated to eliminate the pathogen.

The high sensitivity of nested-PCR analyses, irrespective of the variety of sugarcane tested (susceptible standard or commercial), allows to infer that none of the heat treatments was able to completely eliminate the bacteria from the one- or three-bud setts. However, in all the cases, including the control (not treated), the bacterial level declined from an initial DNA concentration greater than or equal to $2.5 \times 10^{-2} \eta g \mu \mathrm{L}^{-1}$ (Figure $3 \mathrm{a}$ ), detected by conventional PCR (before submitting the setts to heat treatment), to a bacterial DNA concentration below $2.5 \times 10^{-5} \eta g \mathrm{~L}^{-1}$ (Figure $3 \mathrm{~b}$ ), detectable only by nested-PCR, after cutting, heat treatment and planting.

Possible reductions in the bacterial titers have direct and indirect causes, such as environment and temperatures unfavorable to the development of $L x x$ bacteria in stalks and buds, given that both experiments were conducted at the coldest time of the year. The decline may also be due to an interruption in the normal sap flow after stalks are cut into setts, bacterial dilution in the growth phase of new tillers, or slow $L x x$ bacteria growth owing to their fastidious habit. In a study of bacteria, Chalkley \& Koornhof (1985) found an Escherichia coli generation time (non-fastidious) of $15 \mathrm{~min}$, which contrasts with that of fastidious $L x x(6.9 \mathrm{~h})$.

All the treatments resulted in lower bacterial levels, including the untreated control. None of the treatments completely eliminated $L x x$ from the setts. These outcomes corroborate those of Carvalho et al. (2016), who developed a protocol to assess different heat treatment combinations, using quantitative PCR, and also found that the heat treatment only reduced bacterial levels in treated setts. Quantitative PCR also demonstrated that the decrease was greater in setts treated for more than one hour at temperatures of $50^{\circ} \mathrm{C}$ and $52^{\circ} \mathrm{C}$, if compared to shorter treatments and the control.

Corroborating these results, several studies demonstrated that the heat treatment does not completely sanitize sugarcane seedlings (Damann \& Benda 1983, Benda 1994, Grisham et al. 2007, Urashima \& Grachet 2012). Moreover, the active ingredient kasugamycin, in conjunction with the thermotherapy of setts, was not effective at eliminating $L x x$.

Thus, the present study reinforces the need to use more sensitive and reliable techniques on a large scale to assess the efficiency of treatments aimed at eliminating $L x x$ from sugarcane stalks used to propagate the crop.

The degradation of DNA in dead cells is a complex process that is dependent on a specific organism physiology and conditions leading to cell death. In general, intracellular DNA degradation seems to be a slow process, and, in most cases, extracellular DNA can be recovered from decomposing cells (Nielsen et al. 2007). In this study, the plant tissues were sampled at 9 months after thermotherapy; therefore, it is unlikely that dead bacterial cells were still present, but this possibility cannot be completely disregarded, since one possible problem of using PCR and related techniques to evaluate the capacity of a given method to eliminate a pathogen is that PCR cannot discriminate between living and dead cells. 
Serological techniques for diagnostic examinations have been used as part of the integrated management of the ratoon stunting disease in a number of countries (Rao et al. 2004, Fernandes Júnior et al. 2010). Since a significant portion of Dot Blot analyses is efficient only in plants with high infection levels, most of the propagative material analyzed, used in crops around the world and considered $L x x$-free, may be propagating the bacteria at very low bacterial titers. Urashima \& Grachet (2012) improved the Dot Blot sensitivity with a higher initial sample volume, but were unsuccessful with conventional PCR reactions.

In the present study, high sensitivity levels were obtained with the nested-PCR protocol suggested by Davis et al. (1998), tested and adapted here, making it possible to diagnose the ratoon stunting disease in a large number of samples, since it is highly specific, sensitive, fast, does not require sophisticated equipment and allows samples to be stored for a longer period before processing, as it occurs with samples used in conventional PCR.

\section{CONCLUSIONS}

1. Nested-PCR is a useful tool to detect the presence of $L x x$ in setts that will be used as seedlings;

2. None of the treatments applied in thermotherapy, associated or not with kasugamycin, was able to eliminate $L x x$ from the treated setts, including the standard treatments of $50{ }^{\circ} \mathrm{C} / 2 \mathrm{~h}$ and $52^{\circ} \mathrm{C} / 30 \mathrm{~min}$ adopted by sugarcane producers;

3. The treatments decreased the bacterial population, since $L x x$ was only detected by Nested-PCR and not PCR.

\section{ACKNOWLEDGMENTS}

The authors would like to thank the Conselho Nacional de Desenvolvimento Científico e Tecnológico (CNPq) and Coordenação de Aperfeiçoamento de Pessoal de Nível Superior (Capes), for financial support. This study would not have been possible without the equipment provided by the Fundação de Amparo à Pesquisa do Estado de Goiás (FAPEG) and the experimental area made avaliable by the Jalles Machado Industry.

\section{REFERENCES}

BENDA, G. T. A. Serial hot-water treatment for sugarcane disease control. In: RAO JUNIOR, G. P. et al. (Eds.).
Current trends in sugarcane pathology. New Delhi: International Books and Periodicals Supply Service, 1994. p. 297-310.

BOITEUX, L. S.; FONSECA, M. E. N.; SIMON, P. W. Effects of plant tissue and DNA purification method on RAPD-based genetic fingerprinting analysis in carrot. Journal of the American Society of Horticultural Science, v. 124 , n. 1, p. 32-38, 1999.

BRUMBLEY, S. M. et al. Recent advances in the molecular biology of Leifsonia xyli subsp. xyli, causal organism of ratoon stunting disease. Australasian Plant Pathology, v. 35, n. 6, p. 681-689, 2006.

CARNEIRO, J. J. B. et al. Especificidade de anti-soro policlonal à Leifsonia xyli subsp. xyli. Fitopatologia Brasileira, v. 29, n. 6, p. 614-619, 2004.

CARVALHO, G. et al. Development of a qPCR for Leifsonia xyli subsp. xyli and quantification of the effects of heat treatment of sugarcane cuttings on Lxx. Crop Protection, v. 80, n. 1, p. 51-55, 2016.

CHALKLEY, L. J.; KOORNHOF, H. J. Antimicrobial activity of ciprofloxacin against Pseudomonas aeruginosa, Escherichia coli, and Staphylococcus aureus determined by the killing curve method: antibiotic comparisons and synergistic interactions. Antimicrobial Agents and Chemotherapy, v. 28, n. 2, p. 331-342, 1985.

DAMANN, J. K. E.; BENDA, G. T. A. Evaluation of commercial heat treatment methods for control of ratoon stunting disease of sugarcane. Plant Disease, v. 67, n. 9, p. 966-967, 1983.

DAVIS, M. J.; BAILEY, R. A. Ratoon stunting. In: ROTT, P. et al. (Eds.). A guide to sugarcane diseases. Montpellier: CIRAD/ISSCT, 2000. p. 49-54.

DAVIS, M. J.; ROTT, P.; MONGE, G. A. Nested, multiplex PCR for detection of both Clavibacter xyli subsp. xyli and Xanthomonas albilineans in sugarcane. In: INTERNATIONAL CONGRESS OF PLANT PATHOLOGY, 1998, Birmingham. Offered papers. Edimbourg: Royaume-Uni, 1998. p. 3-5.

DIAS, V. D. et al. Comparison of loop-mediated isothermal amplification, polymerase chain reaction, and selective isolation assays for detection of Xanthomonas albilineans from sugarcane. Tropical Plant Pathology, v. 43, n. 4, p. 351-359, 2018.

FERNANDES JÚNIOR, A. R. et al. Avaliação de diferentes tratamentos térmicos no controle do raquitismoda-soqueira em cana-de-açúcar. Tropical Plant Pathology, v. 35, n. 1, p. 60-64, 2010.

GAGLIARDI, P. R.; CAMARGO, L. E. A. Resistência de variedades comerciais de cana-de-açúcar ao agente causal do raquitismo-da-soqueira. Ciência Rural, v. 39, n. 4, p. 1222-1226, 2009.

GRISHAM, M. P.; JOHNSON, R. M.; VIATOR, R. V. Effect of ratoon stunting disease on yield of recently 
released sugarcane cultivars in Louisiana. Journal of the American Society of Sugar Cane Technologists, v. 29, n. 1, p. 119-127, 2009.

GRISHAM, M. P.; PAN, Y. B.; RICHARD, J. E. P. Early detection of Leifsonia xyli subsp. xyli in sugarcane leaves by real-time polymerase chain reaction. Plant Disease, v. 91, n. 4, p. 430-434, 2007.

HARRISON, N. A.; DAVIS, M. J. Colonization of vascular tissues by Clavibacter xyli subsp. xyli talks of sugarcane cultivars differing in susceptibility to ratoon stunting disease. Phytopathology, v. 78, n. 6, p. 722-727, 1998.

HOY, J. W. et al. Effect of tissue culture explant source on sugarcane yield components. Euphytica, v. 129, n. 2, p. 237-240, 2003.

IGLESIAS, A. Review of ratoon stunting disease of sugarcane (Leifsonia xyli subsp. xyli). Revista de Protección Vegetal, v. 18, n. 1, p. 1-6, 2003.

MONTEIRO-VITORELLO, C. B. et al. The genome sequence of the gram positive sugarcane pathogen Leifsonia xyli subsp. xyli. Molecular Plant Microbe Interactions, v. 17, n. 8, p. 827-836, 2004.

NGARUIYA, P. N.; SHIPTON, W. A.; COVENTRY, R. Ratoon stunting disease of sugarcane as influenced by environmental stressors. Proceedings of the Australian Society of Sugar Cane Technologists, v. 27, n. 1, p. 324333, 2005.

NIELSEN, K. M.; JOHNSEN, P. J.; BENSASSON, D.; DAFFONCHIO, D. Release and persistence of extracellular DNA in the environment. Environmental Biosafety Research, v. 6, n. 1, p. 37-53, 2007.

PELOSI, C. S. et al. Development of a Taqman real-time PCR assay for detection of Leifsonia xyli subsp. xyli. Tropical Plant Pathology, v. 38, n. 4, p. 343-345, 2013.
RAMOS, A. T. M. Avaliação da cinética populacional de Leifsonia xyli subsp. xyli em resposta a fatores do hospedeiro e do ambiente. 2012. $86 \mathrm{f}$. Tese (Doutorado em Fitopatologia) - Escola Superior de Agricultura Luiz de Queiroz, Universidade de São Paulo, Piracicaba, 2012.

RAO, G. P.; GIRAD, J. C.; ROTT, P. Current scenario and future perspectives of sugarcane bacterial diseases. In: RAO, G. P.; SAUMTALLY, A. S.; ROTT, P. (Eds.). Sugarcane pathology: bacterial and nematode diseases. New Hampshire: Science Publishers, 2004. p. 3-12.

SANDHU, S. K. et al. Field performance of micropropagated plants and potential of seed cane for stalk yield and quality in sugarcane. Sugar Tech, v. 11, n. 1, p. 34-38, 2009.

TAYLOR, P. M. J. et al. Development of PCR-based markers for detection of Leifonia xyli subsp. xyli in fibrovascular fluid of infected sugarcane plants. Australasian Plant Pathology, v. 32, n. 3, p. 367-375, 2003.

URASHIMA, A. S.; GRACHET, N. G. Métodos de detecção de Leifsonia xyli subsp. xyli e efeito da termoterapia na brotação das gemas de diferentes variedades de cana-de-açúcar. Tropical Plant Pathology, v. 37, n. 1, p. 57-64, 2012.

YOUNG, A.; BRUMBLEY, S. Ratoon stunting disease of sugarcane: history, management and current research. In: RAO, G. P.; SAUMTALLY, A. S.; ROTT, P. (Eds.). Sugarcane pathology: bacterial and nematodes diseases. New York: Enfield Science, 2004. p. 97-124.

ZEKARIAS, Y. et al. Effect of Leifsonia xyli subsp. xyli concentration on yields of four sugarcane varieties in the sugarcane plantations of Ethiopia. Ethiopian Journal of Science and Technology, v. 3, n. 2, p. 25-30, 2012. 